\title{
The Effect of Brown Coal Mining on the Environment and Health of the Population in Northern Bohemia (Czech Republic)
}

\author{
Petr Vrablik, Eliska Wildova, Jaroslava Vrablikova \\ Faculty of Environment, J. E. Purkyne University, Usti nad Labem, Czech Republic \\ Email:Wildova.Eliska@gmail.com
}

How to cite this paper: Vrablik, P., Wildova, E. and Vrablikova, J. (2017) The Effect of Brown Coal Mining on the Environment and Health of the Population in Northern Bohemia (Czech Republic). International Journal of Clean Coal and Energy, 6, 1-13.

https://doi.org/10.4236/ijcce.2017.61001

Received: December 5, 2016

Accepted: January 7, 2017

Published: January 10, 2017

Copyright $\odot 2017$ by authors and Scientific Research Publishing Inc. This work is licensed under the Creative Commons Attribution International License (CC BY 4.0).

http://creativecommons.org/licenses/by/4.0/

(c) (i) Open Access

\begin{abstract}
Coal mining has proven negative impacts on the landscape and health of inhabitants. Solid dust particles and $\mathrm{SO}_{2}$, which are the main polluting substances in coal mining and burning, are the main causes of diseases in areas with intensive coal mining. This contribution deals with areas in the Czech Republic which have the greatest problems in this regard, being North Bohemia (Chomutov, Most, Teplice and Ústí nad Labem districts). It is an area with considerable anthropogenic activity, mainly due to the intensive mining of brown coal, which has a direct effect on the health of the inhabitants of the entire Ústí nad Labem region. Along with the growing number of inhabitants, energy consumption demands are constantly increasing. Nevertheless, it's important to focus primarily on renewable energy sources, which will ensure the sustainable development of the environment and society. At the same time, the question arises, which energy sources can potentially be utilized here after mining ends (2052). In terms of geography, wind energy has the greatest potential in this area. This and associated issues are dealt with by the project "Sustainable Forms of Management in an Anthropogenically Burdened Region" at the Faculty of Environment at the University of Jan E. Purkyně in Ústí nad Labem.
\end{abstract}

\section{Keywords}

Coal Mining, Health of Population, Sustainable Development, Northern Bohemia, Air Quality

\section{Introduction}

For almost 200 years, the surface mining of coal has been the main anthropogenic activity in the region of North Bohemia (Figure 1). Its consequences 


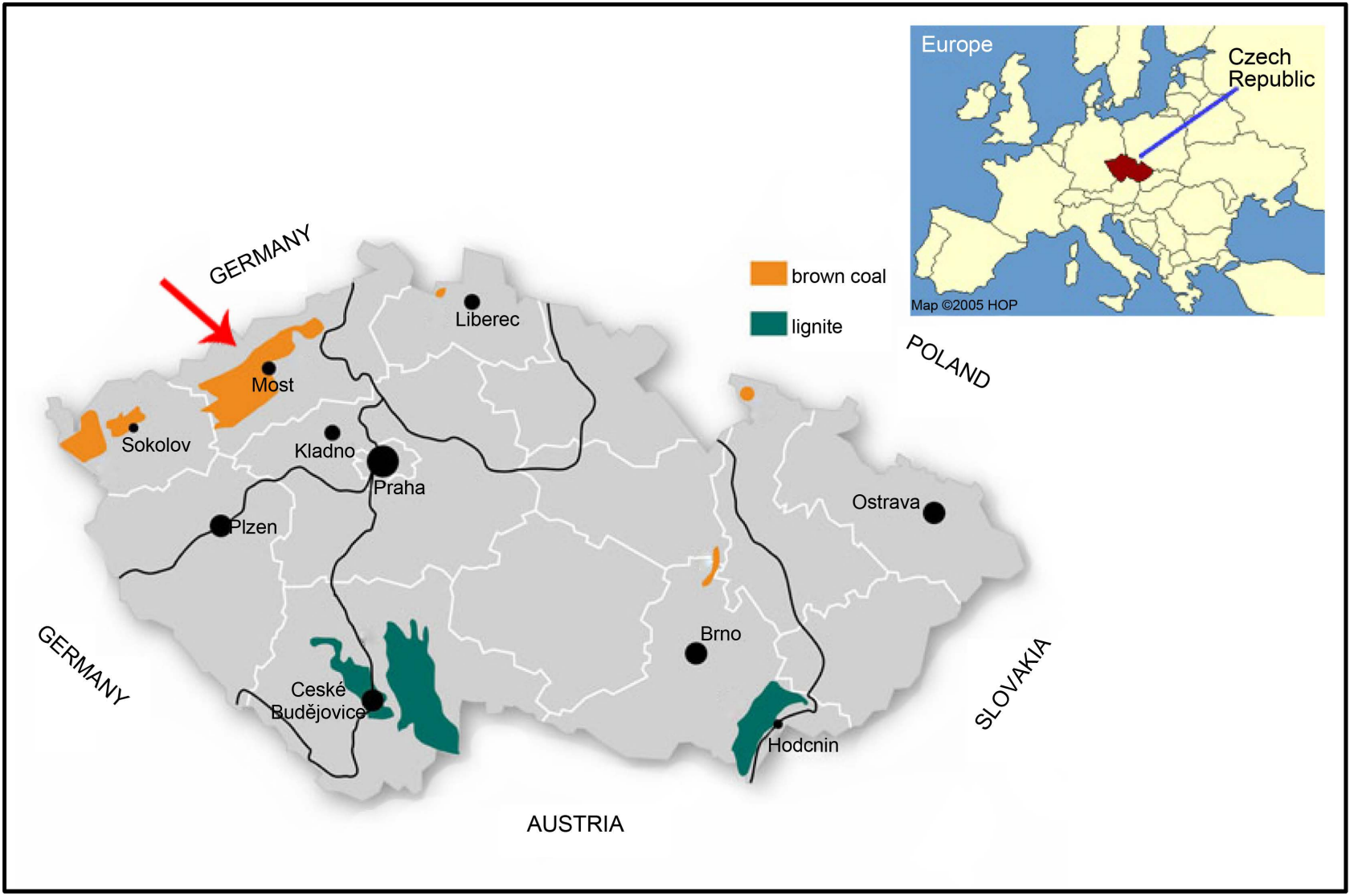

Figure 1. Deposits of brown coal and lignite in the Czech Republic [1].

manifest themselves not only in the landscape, but also in the environment overall; in particular by their negative effects on the health of inhabitants. This does not only mean the population living in the surface quarry's immediate vicinity, but also people living in more remote surroundings, where harmful substances are carried due to the region's dispersive and climatic conditions. The substances created during coal mining and processing are mainly $\mathrm{PM}_{10}$ dust particles, $\mathrm{SO}_{2}, \mathrm{NOx}$ and $\mathrm{CO}$. These substances also have the greatest effect on the circulatory and respiratory systems.

The Ústí nad Labem region, and in particular districts affected by mining (Most, Chomutov, Teplice, Ústí nad Labem), have the worst health indicators in Czech Republic with respect to infant mortality, median life expectancy, incidence of lung cancer and cancer in general and the cancer mortality rate. This sensitive population has been seen long years of exposure to pollution in past decades, which is only manifesting itself now. There may also have been genetic changes which are transferred to the next generation that then reaches adulthood and becomes ill. The exposed population is also aging, which is a typical trend for the entire Czech Republic in recent years, and a high chronic morbidity rate occurs in it from old exposure to chemical substances, aerosols and other factors. We must constantly address the relationship between environmental pollution and its effect on health.

At present, there has been a partial breakthrough in local mining limits, which 
is why the regeneration of the region and a transfer to renewable energy sources will be very important in the future. In order to ensure that the anthropogenically burdened area of North Bohemia develops properly, it is important that we abide by the principle of sustainable development, which takes into account important ecological, economic and social-health aspects of the environment.

\section{Materials and Methods}

\subsection{Sustainable Development}

Sustainable Development is a basic prerequisite for the development of contemporary society, and should be in the first place during planning processes in any industry. It is the most heard and uttered concept within the scope of worldwide conferences and summits, and its basic objective is essential for a proper approach to global development.

- Permanently sustainable development is a targeted process of changes in the behavior of human society.

- Development is perceived as the achievement of the highest sustainable quality of life, or alternatively an increase in the potential to satisfy human needs.

- Development should secure not only intergenerational but also intergenerational equality (fairness) in satisfying human needs (preservation of the option of choice for future generations).

- Development should support harmony between people and nature, life within the boundaries of the biosphere's tolerable capacity, and possibly ensure equality in the distribution of assets, or alternatively in the satisfaction of other beings' needs [2].

\subsection{Coal Mining in the Area of Interest}

A particularly important source for analyzing the development of coal mining and recultivation in the North Bohemian Brown Coal District was data from the State Mining Administration (Mining Yearbooks) from the years 2005-2015. In order to ensure the sustainable development of the landscape after coal mining, one must follow its revitalization methodology and abide by its individual phases and stages.

Raw mineral mining is the most serious anthropogenic activity in the region. It includes both underground and surface mining. In North Bohemia, the most obvious anthropogenic geomorphology, i.e. the result of man's direct interference with the original and surface, is in the area of brown coal surface quarries. Not only physical-chemical effects, such as dust, noise and fumes, but also aesthetic perception were and still are very strong. Of the total expanse of the model area $\left(2276 \mathrm{~km}^{2}\right)$, a significant part of its southern, basinal section is directly affected by surface mining, large-scale external dumps and other related anthropogenic interference with the region and its vegetation. Since the 1960s, 116 municipalities or parts thereof have been liquidated here, including the historical part of the city of Most. At the same time, almost 90 thousand people were relocated. The concentration of production activities leads to an enormous emission 
and air pollution burden on the region's landscape [3].

Supplies of brown coal in the model area, which have been mined industrially since roughly the year 1850, have conditioned growth in electricity production, the chemical industry and metal processing in the region. From its beginnings until the present day, surface brown coal mining has affected an area of approximately $250 \mathrm{~km}^{2}$, and culminated in a volume of almost 70 million.t/year in the $80 \mathrm{~s}$ (Figure 2).

At present, annual mining in the basin is under a level of 35 million-tonnes, and this production by the region under the Ore Mountains is ensured by the Československé Armády [Czechoslovak Army], Vršany, Jan Šverma, Nástup Tušimice and Bílina quarries. The last underground mine in the basin, the Centrum (Kohinoor) Quarry, mines in terms of closing-down process (Figure 3). In accordance with current plans, and in compliance with the limits in the Czechoslovak Army Quarry, mining in the North Bohemian Brown Coal District (SHR) should end in the years 2052-2055 with the mining of the last coal supplies in the Vršany quarry in the Slatinice mining area. Mining in the Bílina Quarry, whose continuation beyond the originally stipulated limits was decided on by the government in October [4] should end during the same period.

89.7\% of brown coal in the Czech Republic is now mined in the model area, and approximately $40 \%$ of the installed power generation capacity output of the Czech Republic is concentrated in it on the basis of solid fossil fuels (steam power stations), of whose fuel base brown coal comprises approximately $85 \%$. The indicated concentration of production activities leads to an enormous emission and air pollution burden on the region's landscape, and plays a part in the low comparative evaluation of the region's environmental quality factor within the scope of the Czech Republic.

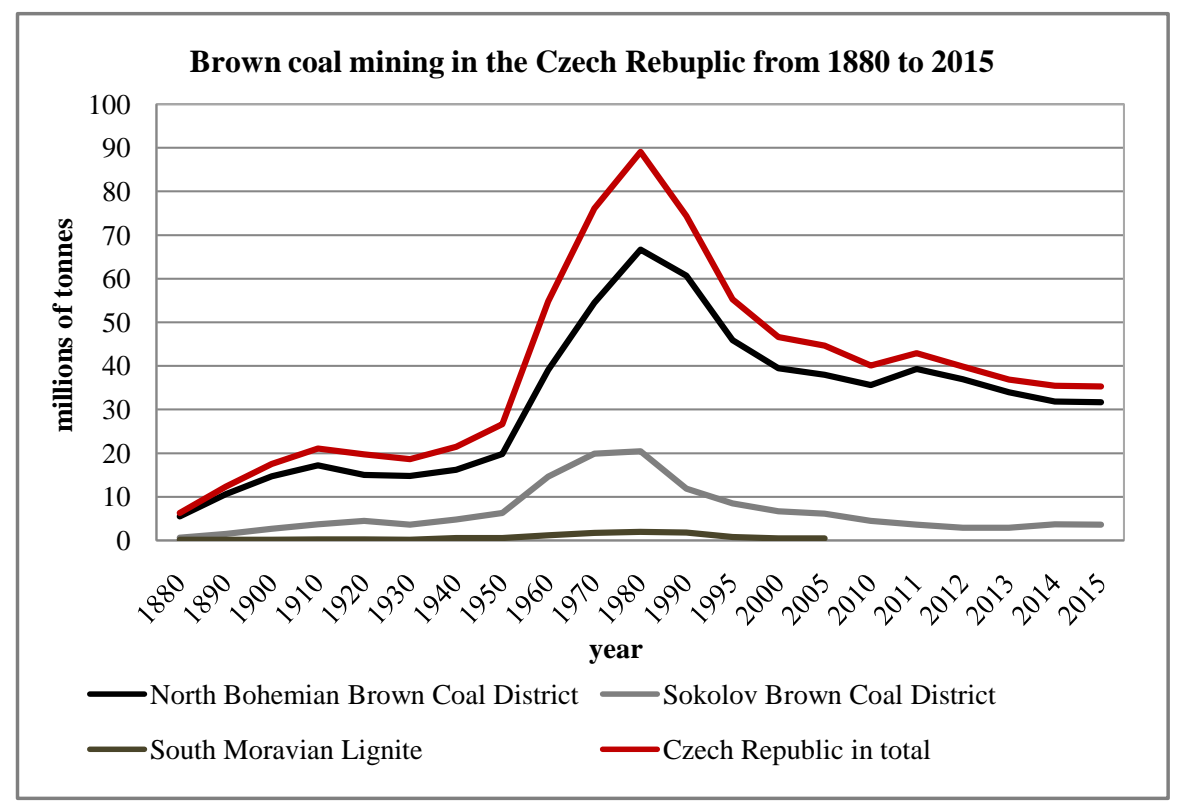

Figure 2. Historical development of brown coal mining in the Czech Republic from the year 1880 [5]. 
Development of brown coal mininng in the resecrah area in the years 2005-2015

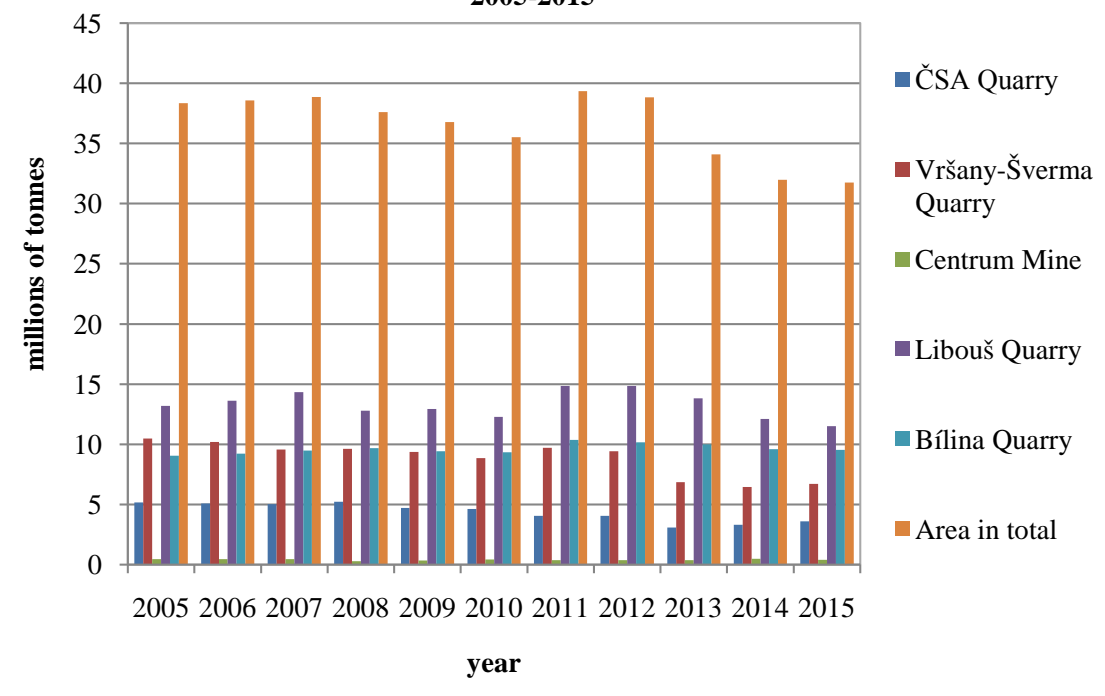

Figure 3. Development of coal mining in the research is in the years 2005-2015 [5].

\subsection{Air Pollution-Emissions}

Even post-war industrial development was accompanied by air pollution. The apparent effect on the environment came as early as the fifties. The vegetation in Jezeři and on the hillside of the Ore Mountains was damaged by sulfur dioxide from the nearby chemical factories, but also from the surface quarries and power stations [6]. The pollution was increased by fires and fumes in the surface quarries. The air pollution in the Podkrušnohoří region was related to industrial development, mining, transport and local sources, but also to the region's geography and dispersive conditions. Orography still plays an important part in the climate and weather of the Ore Mountains and the Podkrušnohoři region, and is a factor in the bad dispersive conditions. So-called inversion is applied significantly.

In the $70 \mathrm{~s}$, emissions in the North Bohemian region represented 1.2 milliontonnes of $\mathrm{SO}_{2}$ and almost 1 million tonnes of solid pollutants. In the years 1975-1989, contemporary Czechoslovakia was an important "exporter" of sulfur dioxide to neighboring countries, more so than an "importer". Export was $46 \%-82 \%$ higher than import. The high degree of air pollution reduced the amount of sunlight falling on the land surface, particularly in basinal districts, and thereby worsened natural circulation, especially in the summer months. By comparing the long-term (sunlight) averages in 1926-1950 and 1960-1980, a reduction of $23 \%$ in the sunlight in Teplice was discovered, and one can assume that this reduction was caused by air pollution [7].

The temperature inversion and pollutants were also connected with the formation of fog. The air pollution was also connected with acid rain, which had an average of $\mathrm{pH} 3.4$ in the year 1985. The rain acidity affected soil acidity. Soil acidity grew by $20 \%$ in the years $1970-1983$; in the year $1970,49 \%$ of agricultural land was acidic, and in the year $1983,56 \%$ of the total area was acidic [8]. 
The greatest contribution to air pollution in the Ústí nad Labem region was made by the large sources located in the basinal districts of the North Bohemian region. These were mainly thermal power stations (27\%) (Figure 4) and the Litvínov chemical factory (15\%); the effect of the Mělník power station, Lovosice Chemical Factory in North Bohemia and other large sources was also evident [7].

After the year 1990, thanks to new legislation and investments, there were considerable changes in emissions and air quality. Decree No. 117/1997 Coll., and the emission limit values for sources were fulfilled at the end of the nineties; the statutory deadline was the year 1998. The consequence of this measure was the rapid decrease in $\mathrm{SO}_{2}$ emissions from stationary sources recorded between the years 1994 and 2000. At present, a slightly decreasing tendency of $\mathrm{SO}_{2}$ emissions is still observed in the Ustí nad Labem region. The significant subsequent reduction in solid pollutant emissions reduced the air burden caused by particles containing persistent pollutants, metals and polycyclic aromatic hydrocarbons.

Since the year 1988, there has been a significant reduction in $\mathrm{SO}_{2}$ concentration in the basinal area. To the present day, we can talk about a decrease of several orders of magnitude. However, sulfur dioxide emissions, although reduced, still remain a local problem for the basinal districts of the Ustí nad Labem region. The contribution of large sources may apply under specific dispersive conditions, when smoke plumes from high power station chimneys reach mountain tops. The following graph represents the annual arithmetic averages of $\mathrm{SO}_{2}$ (Figure 5), in seven-year intervals from the year 2000 to the year 2014. The average annual concentrations record a chronological decrease in sulfur dioxide concentration in the Ústí nad Labem region. The Děčín and Litoměřice districts, shown in Figure 5, are the regions adjacent to the model area.

In the Podkrušnohoří region, sulfur dioxide is a pollutant which is present under the legal limit. Nevertheless, in a sensitive population, one can expect an effect on health even in concentrations lower than the limit. The requirements

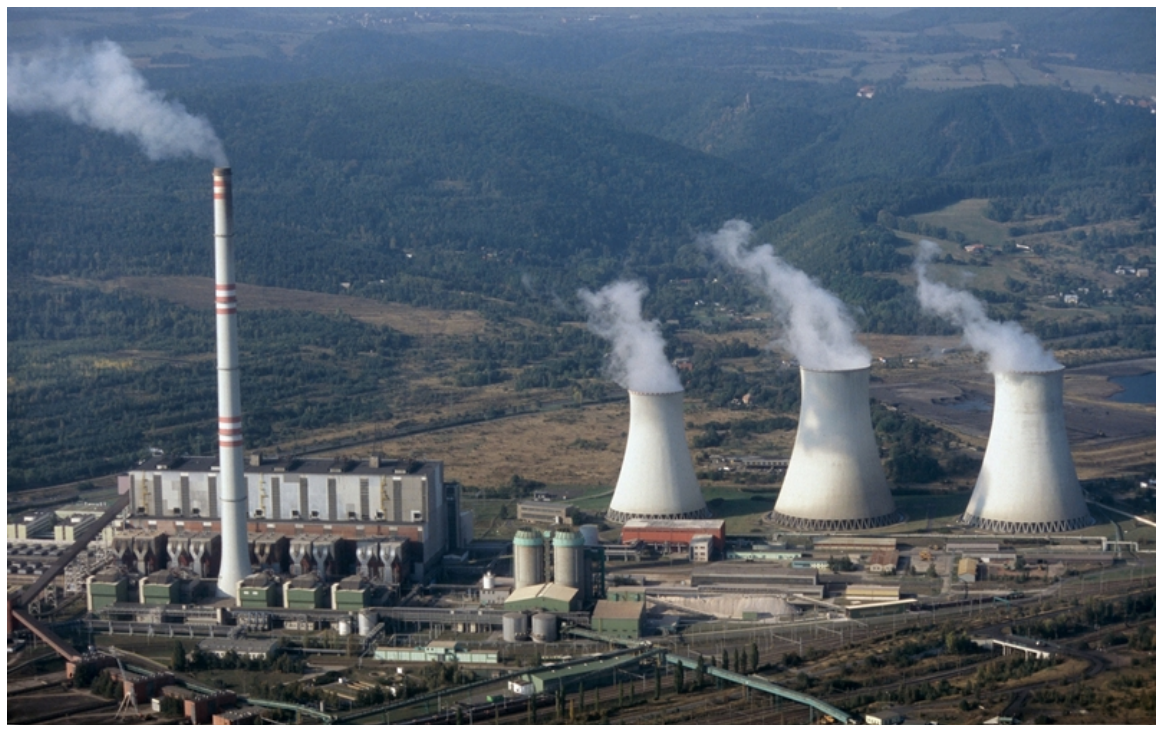

Figure 4. Prunerov thermal power station (2009) [9]. 
stipulated by the World Health Organization set out different limit values than those provided by the monitoring of sulfur dioxide in the air pollution network [8].

Solid dust particles smaller than $10 \mu \mathrm{m}\left(\mathrm{PM}_{10}\right)$ are currently among the main air pollution problems, since their inhalation mainly damages the lung and cardiovascular systems. In the Ústí nad Labem region, the average annual dust particle concentrations have not changed very much over the last 15 years, whereby they have not exceeded $45 \mu \mathrm{g} / \mathrm{m}^{3}$ (Figure 6). Significant differences were not recorded even in the case of daily concentrations. Only in the year 2000 the maximum daily concentration of $260 \mu \mathrm{g} / \mathrm{m}^{3}$ was recorded, in the Litvínov-Lom measuring station.

In studies focusing on chronic obstructive pulmonary disease, asthma and hospital admissions, coarse $\mathrm{PM}_{10}$ particles have a far stronger or almost stronger link to the short-term effect than fine particles, proving that coarse PM particles can lead to damaging processes in the lungs, which activate a process leading to

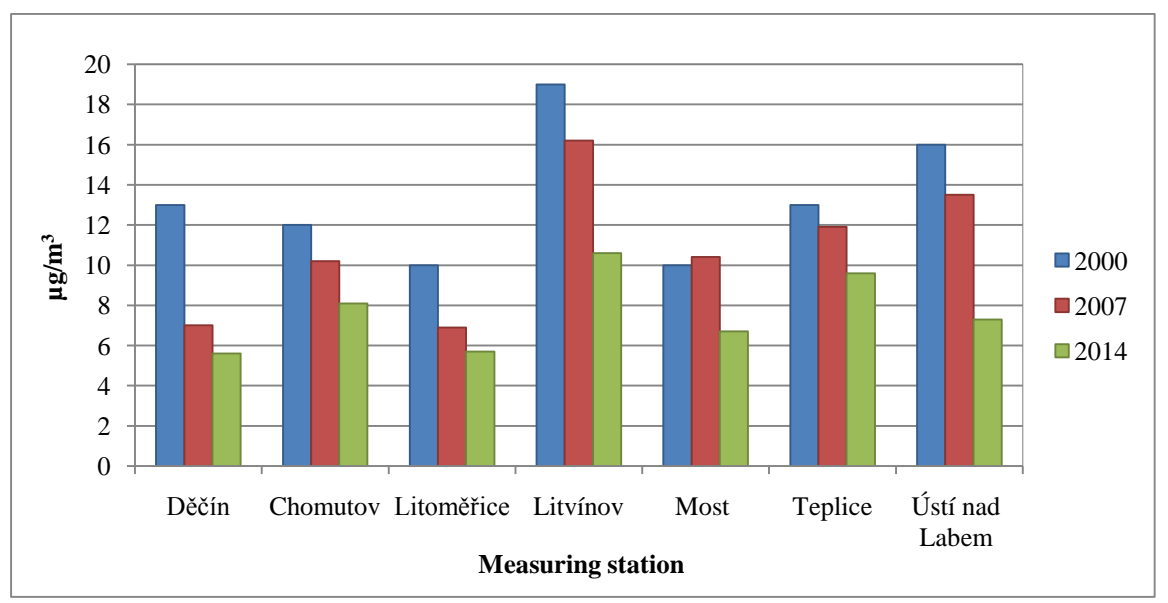

Figure 5. The annual arithmetic averages of sulfur dioxide concentration in $\mu \mathrm{g} / \mathrm{m}^{3}$ in the Ústí nad Labem region in the years 2000, 2007 and 2014 [10].

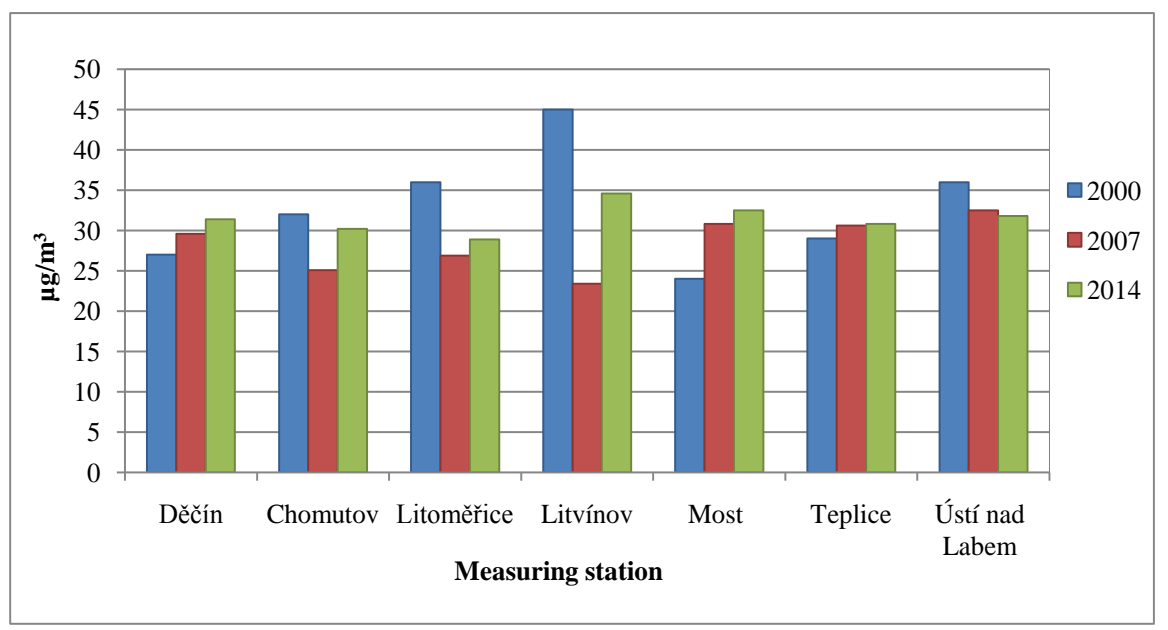

Figure 6. Average annual concentrations of $\mathrm{PM}_{10}$ in $\mu \mathrm{g} / \mathrm{m}^{3}$ in the Ústí nad Labem region in the years 2000, 2007 and 2014 [10]. 
hospital admission. These are also explanations for the admission of patients to hospital due to cardiovascular disease after exposure to $\mathrm{PM}_{10}$.

Large particles are often of crustal origin, such as, silicates, and a large fraction of these coarse particles depends on specific sources. For example, metals in the vicinity of metallurgical operations are their main source. Such coarse particles are around $100 \mu \mathrm{m}$ in size; the larger ones are too heavy and do not stay in the air too long.

In terms of effect on health, the size of the particles is important for application of particle concentrations; if they are respirable and smaller than 2.5 micro$\mathrm{ns}$, they lodge in human alveoli. The relationship between "coarse" $\mathrm{PM}_{10}$ and fine $\mathrm{PM}_{2.5}$ particles differs from place to place, according to the particles' origin. A ratio of $60 \%-80 \%$ is regarded as characteristic for developed countries, where air pollution is dominated by particles from transport. Fortunately, the concentrations discovered in the year 2014 do not exceed the target air pollution value $40 \mu \mathrm{g} / \mathrm{m}^{3}$ in Directive No. 2008/50/EC, on Ambient Air Quality and Cleaner Air for Europe, implemented in national legislation in Government Regulation No. 597/2006 Coll. A higher occurrence of fine $\mathrm{PM}_{2.5}$ dust particles in $\mathrm{PM}_{10}$ in the year 2014 can be found in Kočkov in Ústí nad Labem, Most, Teplice and Doksany (Figure 7). In Tušimice and Lom, small municipalities without significant traffic, where there are surface mines within reach, the relative fine particle content is considerably lower. Apparently coarse particles, probably created mechanically by the separation of rocks during surface coal mining, and being blown off surfaces and unpaved roads, have more of an effect here than fine particles, mostly created secondarily by condensation or coagulation.

\section{Results and Discussion}

Effects of air quality on the health of the population in the research area

The territory of the model area, which has been the subject of research by the

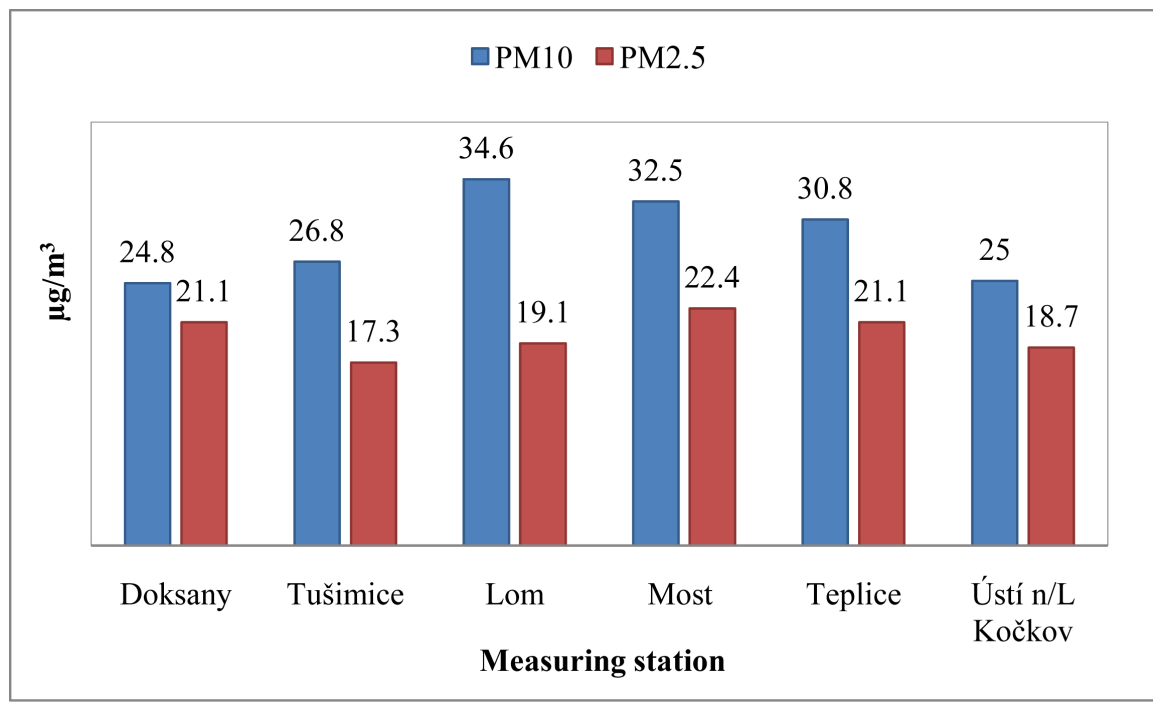

Figure 7. Average annual concentration of $\mathrm{PM}_{10}$ and $\mathrm{PM}_{2.5}$ in $\mu \mathrm{g} / \mathrm{m}^{3}$ in the basinal districts in the year 2014 [10]. 
Faculty of Environment at the University of Jan E. Purkyně in Ústí nad Labem since the year 1992 covers an area of $2276 \mathrm{~km}^{2}$, in which over 485 thousand inhabitants live. It is an area with a high population density, concentrated in cities. The issue of the number of inhabitants, size of the region and number of municipalities in the model area is set forth in Table 1.

Despite the slightly increasing value, life expectancy for both men and women in the Ústí nad Labem region is consistently the most unfavorable of all the regions in the Czech Republic. If, in the Czech Republic, a man born in the year 2013 lives to an average of 75.2 years, then the median life expectancy in the region in 2012 and 2013 is just 73.0 years. While women in the Czech Republic live to an average of 81.1 years, in the region they live to only 79.0. The age structure of the model area's inhabitants copies a trend which is typical for the entire Czech Republic. In the year 2013, the productive population, from 15 to 64 years old, was the best represented (average 68.7\%). However, as the years go by, this population is decreasing and will continue to do so, partly due to young people moving abroad for work. The population of children under 14 years old and people over 65 years old has a very similar share in the age structure between $15 \%$ and $17 \%$.

The number of inhabitants, and its age structure, is an important factor when evaluating the effect of mining on the environment and the health of the inhabitants (Table 2). The most sensitive population groups are mainly children, and people older than 65 . The model area, and by extension the Ústí nad Labem region, records the least favorable health of inhabitants in the entire Czech Republic. This is caused primarily by the quality of the air, which is polluted not only by coal mining and processing, but also by transport. The individual emission burdens in the area of interest are described by Table 3 . The worst air quality is

Table 1. Information about the model area and population (as of 30/6/2016) [11].

\begin{tabular}{cccc}
\hline District & Area in $\mathbf{~ k m}^{2}$ & Number of inhabitants & Number of inhabitants per $\mathbf{1} \mathbf{~ k m}^{\mathbf{2}}$ \\
\hline Chomutov & 935 & 124,357 & 133 \\
Most & 467 & 113,153 & 242 \\
Teplice & 469 & 128,657 & 274 \\
Ústí nad Labem & 405 & 119,414 & 295 \\
Research area in total & 2276 & 485,581 & 213 \\
Ústí nad Labem region & 5335 & 822,272 & 154 \\
\hline
\end{tabular}

Table 2. Age structure of the population in the model area in the year 2014 [12].

\begin{tabular}{cccccc}
\hline \multirow{2}{*}{ District } & \multicolumn{3}{c}{ Population aged (\%) } & \multicolumn{2}{c}{ Average age } \\
\cline { 2 - 6 } & $\mathbf{0 - 1 4}$ & $\mathbf{1 5 - 6 4}$ & $\mathbf{6 5 + \text { years }}$ & Males & Females \\
\hline Chomutov & 15.5 & 68.9 & 15.6 & 39.4 & 41.9 \\
Most & 15.3 & 68.0 & 16.8 & 39.8 & 42.6 \\
Teplice & 15.6 & 67.3 & 17.2 & 39.7 & 42.6 \\
Ústí nad Labem & 16.2 & 66.3 & 17.5 & 39.6 & 42.5 \\
\hline
\end{tabular}


Table 3. Emissions of basic pollutants into the air in the model area in the year 2013 [12].

\begin{tabular}{ccccc}
\hline \multirow{2}{*}{ District } & Particulate matter & $\begin{array}{c}\text { Sulphur dioxide } \\
\left(\mathrm{SO}_{2}\right)\end{array}$ & $\begin{array}{c}\text { Nitrogen oxides } \\
\left(\mathrm{No}_{\mathbf{x}}\right)\end{array}$ & $\begin{array}{c}\text { Carbon monoxide } \\
(\mathrm{CO})\end{array}$ \\
\cline { 2 - 4 } & \multicolumn{4}{c}{ Specific emissions } \\
\hline Chomutov & 6.02 & 79.26 & 79.08 & 28.63 \\
Most & 2.57 & 101.71 & 45.18 & 20.91 \\
Teplice & 2.39 & 60.2 & 29.76 & 16.58 \\
Ústí nad Labem & 1.14 & 19.81 & 10.26 & 14.57 \\
\hline
\end{tabular}

in the Chomutov district, the main factor being very unfavorable high mensural (kg/person) dust particle emissions. Also alarming is the $\mathrm{SO}_{2}$ level in the most districts, which is caused mainly by power stations and coal incinerators. For comparison, the average mensural dust particle emissions in the South Moravian region are $0.2 \mathrm{~kg} /$ inhabitant, and the average mensural $\mathrm{SO}_{2}$ emissions are 1.8 $\mathrm{kg} /$ inhabitant.

According to definitive results in the region, 6273 new diseases involving malignant neoplasms and neoplasms in situ were reported in the year 2013, and the number of new diseases per 100 thousand inhabitants in the region has increased significantly over the last 5 years. Both genders have had an equal share in the number of new diseases. Although the incidence of cancer among men and women in the region has increased, it remains under the national average. In the Chomutov district, there was still an alarming value among women (871 cases per 100 thousand inhabitants), which was high above the national average (766 cases in the Czech Republic). Incidence among men in the region fluctuated between 667 and 864 cases, with the lowest being in the Teplice district and the highest in the Ústí nad Labem district.

In terms of the evaluated indicators, the health of the inhabitants of the Ustí nad Labem region is among the worst among the regions of the Czech Republic. In the vast majority of indicators, it's in the worst position among 14 regions. In terms of development, we can then note these fundamental trends:

- Since the year 1990, life expectancy at birth among women in both the Ústí nad Labem region and the entire Czech Republic has increased by 4.7 years, while among men it has increased by 6.6 years. This is mainly the result of improved health care; first and foremost rapid intervention during brain and cardiac incidents, and also a further decrease in infant mortality, which in the Czech Republic has fallen to one of the lowest rates in the world.

- Despite the afore-mentioned positive changes, mortality conditions in the Ustí nad Labem region are the least favorable, both from an overall perspective and in terms of individual causes.

- Even despite the increasing value, life expectancy for both men and women in the Ústí nad Labem region is constantly the lowest of all the regions in the Czech Republic (approximately 2 years lower than the average among men and women in the Czech Republic).

- While mortality rate from diseases of the circulatory system and malignant 
neoplasms (measured by standardized mortality rates) is decreasing, the discovered cases (incidence) of all malignant neoplasms have a long-term increasing trend.

- In general, the development of health can be characterized by a long-term increasing trend in the occurrence of chronic diabetes, hypertension, Ischemic Heart Disease, cerebrovascular disease and obesity.

- The occurrence of the diseases and their seriousness increases with age, and morbidity and mortality rate is higher among men than women (health support strategy in Charles University).

Figure 8 and Figure 9 represent the standardized mortality rate of the inhabitants of the Ústí nad Labem region from lung cancer during the years 19822007. Compared to the South Moravian region and the entire Czech Republic, the mortality rate from this disease in the Ústí nad Labem region is much

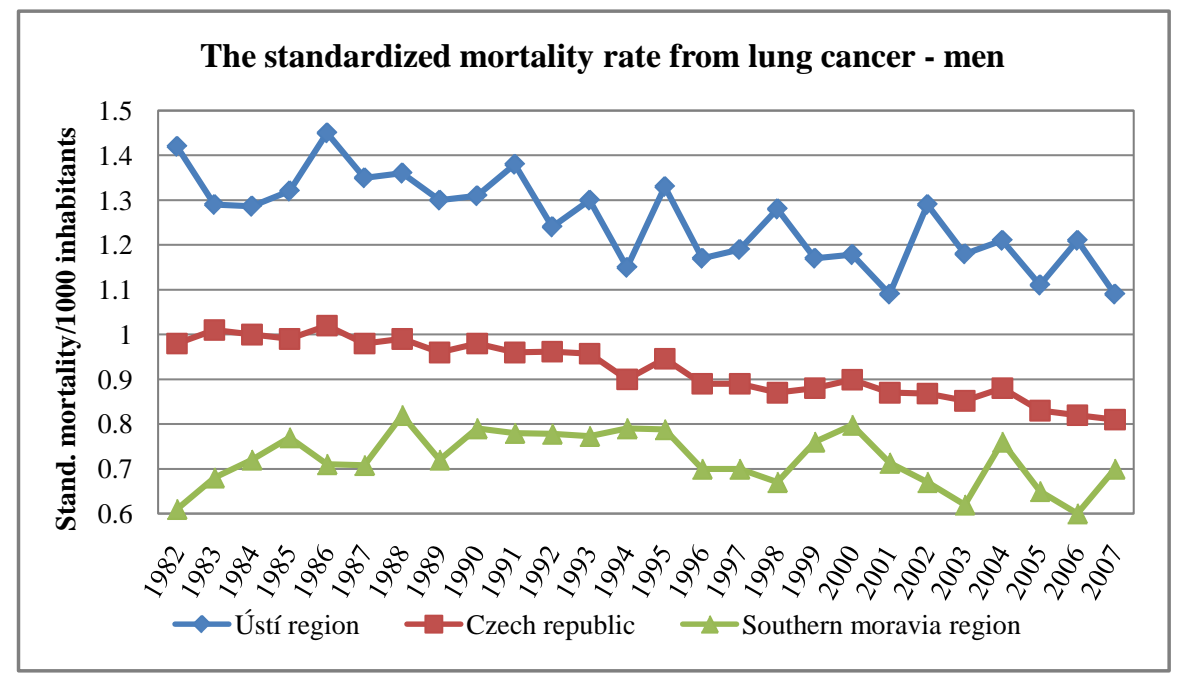

Figure 8. The standardized mortality rate of the inhabitants of the Ústí nad Labem region from lung cancer 1982-2007-men [13].

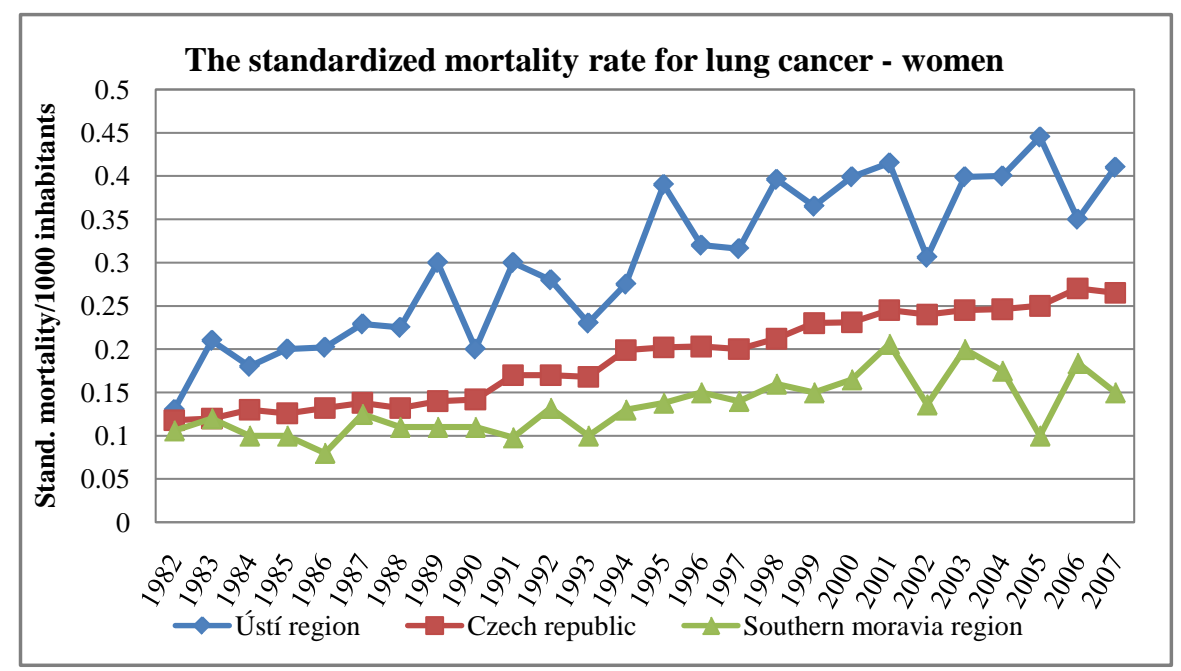

Figure 9. The standardized mortality rate of the inhabitants of the Ústí nad Labem region from lung cancer 1982-2007-women [13]. 
higher for both men and women. The standardized mortality rate from lung cancer among men is decreasing slightly year-on-year, while the reverse is true among women.

\section{Conclusion}

Coal is currently the most important source for energy production in the Czech Republic. However, society's growing demands do not correspond to its existing supplies. Let's hope that we don't live to see another breakthrough of the mining limits in the most basins, as we would simultaneously prolong the inclusion of an anthropogenically disrupted region in the surrounding environment, and the inhabitants' health would constantly worsen. The Ústí nad Labem region is already the least favorable area in terms of the inhabitants' health, even though health care is constantly improving. In order to ensure the sustainable development of not just the landscape, but also society in such a damaged environment, we must focus on analyzing the potential of renewable energy sources with an emphasis on the interconnection of ecological, economical and social aspects, so that the environment is not endangered and at the same time, society's energy demands are satisfied. To achieve the objectives of permanently sustainable development in the energy and industry sectors, we must take gradual steps to secure the creation and development of legislation and measures in the price area, and limit the use of non-renewable sources. The main measures which will help us achieve these objectives are the fuel economy, and meeting consumption from renewable sources. From the perspective of sustainable development, it would be appropriate to differentiate between non-renewable and renewable sources in terms of tax. Impose tax penalties on non-renewable sources, particularly carbonaceous fuels, and provide tax breaks for demonstrably economical technology and business. However, we must not hesitate too much with the decision on the direction which North Bohemian energy is to take, as the last brown coal supplies will be mined in the year 2052 .

\section{Acknowledgements}

This article was supported by Project QJ1520307 entitled "Sustainable Forms of Management in an Anthropogenically Burdened Region". This project was realized with financial support from state budget resources through the KUS Program, Ministry of Agriculture of the Czech Republic.

\section{References}

[1] Vrablikova, J., Wildova, E. and Vrablik, P. (2016) Sustainable Development and Restoring the Landscape after Coal Mining in the Northern Part of the Czech Republic. Journal of Environmental Protection, 7, 1483-1496. https://doi.org/10.4236/jep.2016.711125

[2] Demo, M., Bielek, P. and Hronec, O. (1999) Permanently Sustainable Development. 1st Edition, Slovak University of Agriculture, Nitra, Research Institute of Soil Sciences and Soil Protection, Bratislava, 400 p.

[3] Vrablikova, J., et al. (2011) Land Revitalization of North Bohemia. University of J. 
E. Purkyne, Ustí nad Labem.

[4] Kašpar, J. (2015) The Effect of Mining on the Landscape of the Area of Interest (Most Region) and Its Regeneration. Sub-Report for Project QJ1520307-Sustainable Forms of Management in an Anthropogenically Burdened Region. 19 p.

[5] State Mining Administration Workers' Collective (2016) Mining Yearbook 20052015. The Czech Mining Authority and the Employers' Association of the Mining and Oil Industries, Ostrava.

[6] MEMORANDUM of 21/2/1949, Presented to the Regional National Committee in Ústí nad Labem, Regional Planning Commission Chairman Ing. Hora, KHS Historical Documentation.

[7] Anděl, J. (1990) Evaluation of the State and Development of the Environment in the North Bohemian Region, Prague. VÚVA, 123 p.

[8] Rychlíková, E. (2015) The Air in the Ústí nad Labem Region, and the Health of the Population. Sub-Report for Project QJ1520307-Sustainable Forms of Management in an Anthropogenically Burdened Region. 12 p.

[9] Berger, J. (2009) Photography of Prunerov Thermal Power Station. Aerial Photo.

[10] ČHMÚ [Czech Hydrometeorological Institute] (2014) Tabular Yearbooks. Air Pollution and Atmospheric Deposits in Dates. Air Quality Protection Division. http://portal.chmi.cz/

[11] ČSÚ [Czech Statistical Office] (2016) Statistical Bulletin of the Ústí nad Labem Region for the 1st and 2nd Quarter of 2016.

[12] Czech Statistical Office, Ústí nad Labem (2016) Statistical Yearbook of the Ústí nad Labem Region 2015. 239 p.

[13] Rychlíková, E., Skorkovský, J. and Pánková, R. (2013) Evaluation of the Effects on Public Health of the "Development Program of the Ústí Region 2014-2020" as Per Act No. 100/2001 Coll., as Amended. Health Institute Based in Ústí nad Labem, 43 p.

Submit or recommend next manuscript to SCIRP and we will provide best service for you:

Accepting pre-submission inquiries through Email, Facebook, LinkedIn, Twitter, etc. A wide selection of journals (inclusive of 9 subjects, more than 200 journals)

Providing 24-hour high-quality service

User-friendly online submission system

Fair and swift peer-review system

Efficient typesetting and proofreading procedure

Display of the result of downloads and visits, as well as the number of cited articles

Maximum dissemination of your research work

Submit your manuscript at: http://papersubmission.scirp.org/

Or contactijcce@scirp.org 